\title{
Korporatisme Pedesaan Orde Baru: Program Tebu Rakyat Intensifikasi (TRI) di Wilayah Kerja Pabrik Gula Mojo Sragen, 1975-1998
}

\author{
Prima Dwianto \\ Mahasiswa S1 Jurusan Sejarah Universitas Gadjah Mada
}

\begin{abstract}
Abstrak
Pemerintah Indonesia merubah secara radikal struktur industri gula nasional dengan mengeluarkan Instruksi Presiden Nomor 9 Tahun 1975 tentang Program Tebu Rakyat Intensifikasi (TRI) untuk meningkatkan produktivitas gula. Ketergantungan proses produksi terhadap pabrik gula mulai dikurangi dan dialihkan kepada petani yang menjalankan proses produksi mulai dari penanaman hingga masa panen. Penelitian ini bertujuan untuk mendokumentasikan dampak sosial-ekonomi dari pelaksanaan Program TRI terhadap petani di wilayah kerja Pabrik Gula Mojo Sragen pada 1975-1998. Hasil penelitian menunjukkan bahwa petani di wilayah selatan Bengawan Solo menolak pelaksanaan Program TRI karena tanaman padi lebih menguntungkan. Para petani melakukan protes sosial dengan membakar tebu sebagai bentuk kekecewaan. Sementara itu, petani di wilayah utara mendukung pelaksanaan Program TRI karena penanaman tebu di wilayah kering lebih menguntungkan dibandingkan penanaman tanaman lainnya seperti palawija. Penelitian ini membuktikan bahwa Program TRI dapat memberikan dampak positif terhadap petani, berbeda dengan penelitian-penelitian sebelumnya yang mengungkapkan bahwa Program TRI selalu berdampak buruk terhadap petani.
\end{abstract}

Kata kunci: tebu, Pabrik Gula Mojo Sragen, program TRI, Orde Baru, Revolusi Hijau

\begin{abstract}
The Indonesian government has radically altered the structure of the national sugar industry by issuing Presidential Instruction no 9/1975 on the People's Sugarcane Intensification Program (TRI) in order to increase sugar productivity. The dependence on the production process to sugar factories was replaced with the production process of the farmers from planting to harvesting. This research intends to document the socio-economic effects of the TRI program on farmers within the Mojo Sugar Factory work area in Sragen, Central Java, between 1975 until 1998. The result of the research has shown that farmers south of the Bengawan Solo river were resistant to the TRI program in favor of more lucrative rice farming. These farmers conducted social protests such as sugarcane field burnings. Farmers that lived north of the river supported the TRI program because planting sugarcane on non-irrigated fields was more profitable than planting other crops. This research shows that the TRI program has positively benefited to some
\end{abstract}


farmers, a conclusion that is not shared by previous researches that point to only negative effect of the program.

Keywords: sugarcane, Mojo Sugar Factory Sragen, TRI program, New Order, Green Revolution

\section{Pendahuluan}

Permasalahan di berbagai bidang mengiringi Soeharto yang menggantikan Soekarno sebagai Presiden Republik Indonesia melalui sidang MPRS pada 12 Maret 1967, (Rickleffs, 2008: 605) tak terkecuali pertanian. Permasalahan muncul ketika terjadi tekanan jumlah penduduk yang mengakibatkan kebutuhan beras meningkat. Jumlah penduduk Jawa dan Madura misalnya, meningkat dari 53 juta menjadi 60 juta pada periode 1950-1961. Produksi beras pada periode tersebut hanya mampu memenuhi rata-rata 0,74 kw/orang/tahun, angka yang masih jauh dari standar kebutuhan gizi menurut Sayogo yakni 1,2 kw/orang/tahun (Francis Wahono, 1994: 13-4).

Usaha untuk memenuhi kebutuhan beras telah dirintis semenjak Institut Pertanian Bogor (IPB) melakukan penelitian dan penyuluhan mengenai teknik penanaman padi yang lebih maju pada 1963-1964 di sejumlah desa (Hansen, 1972). Peningkatan produktivitas padi dilaksanakan dengan menerapkan panca usaha tani, yakni irigasi yang baik, bibit unggul, pemupukan, penggunaan pestisida dan penanaman padi yang lebih sistematis (Selo Soemardjan, 1993: 82-3). Sebagai tindak lanjut, pada masa Orde Baru, sebutan untuk pemerintahan di bawah di bawah Soeharto, pemerintah mengadopsi konsep Revolusi Hijau (Green Revolution) yang sedang marak diterapkan di negara berkembang. Pemerintah mengontrak salah satu perusahaan farmasi dan kimia dari Swiss, CIBA, untuk menyediakan bibit unggul, pupuk, serta pestisida bagi 300.000 ha lahan padi di Jawa pada 1968 (Hansen, 1972: 937). Swasembada beras dapat dicapai pada 1984-
1985 dengan kemampuan penyediaan beras rata-rata 1,6 kw/orang, salah satu keberhasilan terbesar pemerintah Orde Baru (Francis Wahono, 1994).

Keberhasilan swasembada beras menyebabkan tekanan pada industri yang sudah sejak masa kolonial diusahakan, yakni industri gula, terutama dalam hal penyediaan lahan untuk menanam tebu. Keadaan semakin diperparah dengan tingginya jumlah konsumsi gula dalam negeri jika dibandingkan tingkat produksi gula yang dapat dicapai. Indonesia harus mengimpor gula sejak 1967 untuk dapat memenuhi konsumsi dalam negeri (Mubyarto dan Daryanti, 1991: 15). Situasi politik ikut mempengaruhi proses produksi gula. Kampanye melawan PKI (Partai Komunis Indonesia) dengan pembunuhan terhadap anggota serikat buruh dan aktivis petani yang berasosiasi dengan pabrik gula terjadi pada 1965 mengakibatkan proses produksi terganggu (Knight, 2012: 402). Sebagai akibatnya, luas lahan tebu mengalami penurunan dari 87.408 ha pada 1965 menjadi 80.819 ha pada tahun berikutnya (Novi Indiarto Soentoro dan Abd. Muis S. Ali, 1999: 70).

Masuknya pinjaman asing memungkinkan Pemerintah Orde Baru menjalankan program menghadapi permasalahan penyediaan gula. Beberapa pinjaman asing masuk seperti IGGI (Inter Governmental Group on Indonesia), IMF (International Monetary Found), serta Bank Dunia (World Bank) (Sjahrir, 1992: 48). Beruntung pula, pemerintah mendapatkan berkah dari naikknya harga minyak (oil boom) di pasaran dunia pada 1973 (van Zanden dan Marks, 2012: 347). Modal asing digunakan pemerintah 
untuk menekan tingginya angka inflasi pada masa pemerintahan Soekarno yang mencapai $650 \%$ pada 1966, dapat ditekan menjadi 40$50 \%$ pada 1968 (Sjahrir, 1992). Pemerintah menjalankan pula sebuah program yakni Repelita (Rencana Pembangunan Lima Tahun) pada 1969-1974. Namun, usaha pemerintah dalam bidang pergulaan yang dijalankan melalui penyempurnaan sistem pemasaran serta pengurangan beban pajak belum mampu mengatasi pemasalahan pada industri gula nasional secara maksimal (Murbyarto, 1984: 62-5).

Pemerintah akhirnya mengambil langkah radikal untuk mengatasi permasalahan industri gula nasional. Pemerintah mengeluarkan Instruksi Presiden (Inpres) Nomor 9 Tahun 1975 tentang Program Tebu Rakyat Intensifikasi (TRI) (Dibyo Prabowo, 1994: 2). Program TRI terinspirasi dari keberhasilan Bimas padi. Dominasi pabrik gula dalam produksi dikurangi dengan menjadikan petani sebagai pelaku utama dalam produksi tebu (Mackie, 1992:61-62). Program TRI merubah orientasi industri gula nasional yang semula bergantung pada pabrik gula (mill-controlled) menjadi ketergantungan terhadap petani (smallholder) (Mackie dan O’Malley, 1988: 733). Sistem sewa yang semula diterapkan juga mulai dihapus secara berkala dalam tempo waktu lima tahun.

Program TRI menjadi bagian dari korporatisme Pemerintahan Orde Baru yang diterapkan di wilayah pedesaan. Pemerintah secara otoriter mengontrol masyarakat demi tercapainya pertumbuhan ekonomi secara cepat. Integrasi ekonomi dan politik nasional kedalam dunia internasional dijalankan dengan masuknya modal asing di sektor industri. Regulasi ekonomi dijalankan secara ketat untuk memproteksi produksi dan penjualan pada sektor industri yang penting bagi masyarakat. Sektor pertanian sangat tergantung terhadap infrastruktur dan subsidi yang diberikan oleh pemerintah (Gosh, 1996: 36-8). Program TRI diharapkan mampu meningkatkan pendapatan petani melalui peningkatan produktivitas usahatani tebu dalam rangka meningkatkan produksi gula nasional (Himpunan peraturan2 TRI tahun 1981, 1981).

Penelitian ini menjelaskan mengenai dampak, secara sosial dan ekonomi, dari pelaksanaan Program TRI terhadap petani di wilayah kerja Pabrik Gula Mojo Sragen. Pabrik Gula Mojo merupakan salah satu pabrik gula pelaksana Program TRI di wilayah PNP (Perusahaan Negara Perkebunan) XVI Surakarta. Penting untuk menjelaskan dampak yang dialami petani karena industri gula telah memberikan dampak yang mendalam bagi kehidupan masyarakat Indonesia sejak masa kolonial. Salah satu ungkapan dalam bahasa Belanda berbunyi "de suiker industrie is de kurk waarop Nederlansch Indie drift" (industri gula adalah gabus tempat Hindia Belanda mengapung) (Suara Merdeka, 12 April 1987). Penelitian ini bertujuan untuk dapat menjelaskan sejauh mana dampak sosial ekonomi pelaksanaan Program TRI di wilayah kerja Pabrik Gula Mojo Sragen terhadap petani.

\section{Pelaksanaan Program TRI dalam Lingkup Nasional}

Program TRI secara nasional dilaksanakan setelah adanya Instruksi Presiden (Inpres) Nomor 9 Tahun 1975 tentang Program Tebu Rakyat Intensifikasi (TRI) yang dikeluarkan pada 22 April 1975 (Mubyarto dan Daryanti, 1991 dan Kaman Nainggolan, 2015). Tujuan utama yang ingin dicapai dari pemberlakuan Program TRI adalah menempatkan petani sebagai tuan rumah di atas tanahnya sendiri. Pendapatan petani diharapkan meningkat (Dibyo Prabowo, 1994) seiring dengan meningkatnya produksi gula 
serta produktivitas tebu per hektar (ha) (Jati Isnanto, 2012: 59).

Terdapat, paling tidak, dua jenis Program TRI berdasarkan lokasi pelaksanaannya yakni TRI Sawah (TRIS) serta TRI Tegalan (TRIT). TRIS dilaksanakan di lahan sawah dengan irigasi yang baik sedangkan TRIT dilaksanakan di lahan kering. TRIS dan TRIT digolongkan menurut tingkat pengeprasannya (penebangan). TRIS dibatasi hanya dikepras dua kali (TRIS I dan II), sementara TRIT dapat dikepras hingga tiga kali (TRIT I, II, III) (Mubyarto dan Daryanti, 1991: 46).

Pelaksanaan Program TRI melibatkan berbagai pihak yang menjalankan fungsinya masing-masing dalam menyukseskan pelaksanaan program tersebut. Satuan Pelaksana (Satpel) Bimbingan Massal (Bimas) sebagai pelaksana, BRI (Bank Rakyat Indonesia) yang memberikan kredit, KUD (Koperasi Unit Desa) sebagai penyalur sarana produksi, dan pabrik gula yang memberikan bimbingan saling terkait dalam mekanisme pelaksanaan program TRI (Mubyarto dan Daryanti, 1991). Akan tetapi, keterlibatan berbagai pihak ini seringkali menimbulkan permaslahan seperti terlambatnya pencairan dana kredit. Selain itu, dalam hierarki program TRI, petani justru memiliki kekuasaan yang paling lemah jika dibandingkan pihak lain mengingat penyuluhan mengenai teknis pelaksanaan TRI, penyediaan bibit unggul dan sarana produksi, serta penyaluran kredit, dilakukan oleh lembaga yang lebih berkuasa dibandingkan petani (Daniel Asnur, 1999: 2).

Sistem yang dijalankan dalam program TRI mengindikasikan adanya pelimpahan tanggung jawab produksi gula, yang semula, dari pabrik gula ke petani yang belum menguasai teknologi penanaman tebu secara maksimal. Petani harus mempersiapkan lahan, menanam bibit, memelihara, menebang, serta membawa tebu ke pabrik. Selain itu, para petani TRI harus mengajukan kredit kepada BRI untuk dapat menjalankan usaha tani tebunya (Mubyarto, 1996: 10). Paket kredit yang disediakan pemerintah terdiri dari COL (Cost of Living/Biaya Beban Hidup), biaya garap tanah, sarana produksi, serta biaya tebang dan angkut tebu (Mubyarto dan Daryanti, 1991). Setelah tebu dipanen, petani akan mendapatkan imbalan dengan sistem bagi hasil dengan pabrik gula. Petani hanya memperoleh 25\% dari seluruh hasil gula ditambah $1,5 \mathrm{~kg}$ tetes $/ \mathrm{kw}$ tebu berdasarkan Keputusan Menteri nomor 017/SK. I/MENTAN/BPB/1978 (Himpunan Peraturan2 TRI tahun 1981, 1981: 15). ${ }^{1}$

Partisipasi petani untuk mengikuti Program TRI dapat dikatakan kurang. Meskipun pemerintah telah memberikan insentif agar petani memiliki kemauan untuk menanam tebu, tetapi petani enggan untuk terlibat langsung dalam Program TRI, terutama petani yang memiliki lahan sempit. Resiko kegagalan berupa kerusakan panen, turunnya rendemen akibat penebangan tebu yang terlambat, kesulitan tebang dan pengangkutan, serta sulitnya meningkatkan produksi karena pengetahuan yang rendah tentang penanaman tebu merupakan hal yang dikhawatirkan para petani (Jati Isnanto, 2012: 13). Para petani bahkan memilih untuk menyewakan lahan mereka kepada petani bermodal besar atau ketua kelompok tani dengan mendapatkan uang sewa tanpa harus menanggung resiko dari usaha tani tebu yang dijalankan (Mubyarto, 1996: 10-1).

Peraturan ini diberlakukan pada masa TRI Jasa yakni peralihan menuju TRI sepenuhnya untuk memantapkan kemampuan petani dalam penanaman tebu dan hanya berlaku selama periode Repelita III (1979/19801983/1984). 
Pemerintah melakukan intervensi kepada para petani untuk mengatasi rendahnya partisipasi dalam Program TRI. Di Daerah Bantul Daerah Istimewa Yogyakarta (DIY) misalnya, jika petani menolak untuk menanam tebu Program TRI, akan berhadapan dengan aparat keamanan serta intimidasi dari perangkat desa. Petani akan diinterogasi di kantor Koramil (Komando Rayon Militer). Pabrik Gula Madukismo, yang mengolah tebu TRI di Bantul, telah disewa oleh PT Rajawali yang bekerja sama dengan aparat Koramil serta perangkat kecamatan maupun perangkat desa (Tjahjono Edi P, 2015).

Produktivitas hablur dan rendemen selama 16 tahun menurun sebagai akibat pelaksanaan Program TRI. Produktivitas hablur (kristal gula) pada 1976 masih mencapai 6,99 ton/ha (TRIS) dan 5,79 ton/ha (TRIT) dengan tingkat rendemen 10,26\% (TRIS) dan 10,14 (TRIT). Produktivitas hablur hanya mencapai 7,74 ton/ha (TRIS) dan 4,73 ton/ha (TRIT) dengan rendemen 8,54\% (TRIS) dan 8,08\% (TRIT) pada 1991 (Kompas, 13 Desember 1990). ${ }^{2}$ Akibat yang diterima petani TRI adalah menurunnya pendapatan karena tinggi rendahnya pendapatan petani didasarkan pada tingkat rendemen yang berhasil dicapai. Keinginan pemerintah untuk swasembada gula akhirnya harus diimbangi dengan penanaman tebu di lahan kering yang memiliki produktivitas rendah jika dibandingkan penanaman di lahan sawah (Dibyo Prabowo, 1994: 5).

Kualitas tebu yang dihasilkan di lahan kering tidak sebaik tebu yang ditanam di lahan sawah karena tebu membutuhkan sistem irigasi yang baik. Konsumen gula dalam negeri pada akhirnya harus membeli gula dengan kualitas buruk. Bahkan, harga gula dalam negeri lebih tinggi jika dibandingkan dengan harga gula dunia setelah berlangsungnya Program TRI (Mackie dan O’Malley, 1988). Pada 1984, harga gula internasional hanya berkisar Rp 130/kg sedangkan harga gula di Indonesia mencapai Rp 600/kg (Suara Karya, 10 Januari 1935). Harga gula yang tinggi diakibatkan tingginya biaya produksi yang harus dikeluarkan untuk menanam tebu.

\section{Pelaksanaan Program Tebu Rakyat In- tensifikasi (TRI) di Wilayah Kerja Pabrik Gula Mojo Sragen}

Perbedaan kondisi sosial-ekonomi masyarakat di Sragen menjadikan pembahasan mengenai pelaksanaan Program TRI di wilayah kerja Pabrik Gula Mojo menjadi menarik. Aliran sungai Bengawan Solo membelah wilayah Sragen menjadi dua bagian, yakni utara dan selatan. Wilayah utara atau masyarakat Sragen biasa menyebut 'brang lor (seberang utara) merupakan lahan kering, bagian dari pegunungan Kendeng, dengan pengairan yang cenderung sulit. Sementara itu, wilayah selatan atau 'brang kidul (seberang selatan) memiliki tanah yang subur dan memperoleh pengairan yang cukup. Wilayah selatan merupakan wilayah yang berada di kaki Gunung Lawu (www. sragenkab.go.id). Pusat pemerintahan kabupaten Sragen juga terletak di sebelah selatan Bengawan Solo. Keadaan tersebut menjadikan perkembangan wilayah Sragen cenderung berpusat di sebelah selatan sungai Bengawan Solo. Menurut Paul R. Deuster (1982: 156), konsekuensi dari sebuah inovasi ekonomi dan teknis tidak dapat diramalkan tanpa memperhatikan keadaan suatu tempat. Program TRI merupakan sebuah inovasi yang dijalankan oleh pemerintah dalam usaha untuk meningkatkan produksi gula

2 Tingkat rendemen dilaporkan hanya 7,5\% pada 1990, menurun jika dibandingkan pada 1975 yang mencapai $10,51 \%$. 
nasional dengan melibatkan peran petani tebu secara langsung dalam industri gula.

Pihak Pabrik Gula Mojo, pada awalnya, menyewa tanah yang dimiliki petani dan melakukan pembukaan lahan hingga penebangan tebu. Hubungan yang terjadi antara pihak pabrik dengan petani hanya terbatas pada hubungan sewa tanah. Keadaan ini menjadikan penguasaan teknologi penanaman tebu sepenuhnya dikuasai oleh pihak pabrik gula (Satuan Bimas Kabupaten Sragen, 1988). Sejak berlakunya Program TRI dengan dikeluarkannya Inpres No. 9 tahun 1975, secara berangsur-angsur hingga 1980 sistem sewa tanah diganti dengan Sistem TRI (Satuan Bimas Kabupaten Sragen, 1988). Petani mulai terlibat langsung dalam seluruh proses produksi gula sehingga terjadi alih teknologi dari pabrik gula ke petani.

Program TRI yang dilaksanakan di wilayah Sragen pada musim tanam 1975/1976 hanya TRIS II, TRI di lahan sawah, karena waktu persiapan yang sempit. Pada musim tanam selanjutnya mulai dilaksanakan TRIS I dan II. Akan tetapi, pada masa awal pelaksanaan Program TRI, berbagai permasalahan masih ditemukan. Petani enggan untuk menanggung resiko kerugian yang bisa ditimbulkan dalam masa 16 bulan karena alih teknologi yang belum maksimal dapat menyebabkan hasil panen tidak sesuai dengan apa yang diharapkan. Para petani sukar dimotivasi untuk menanam tebu dan lebih memilih menyewakan tanahnya kepada Pabrik Gula Mojo atau menyerahkan kepada petani penggarap dengan sistem bagi hasil. Sempitnya lahan yang dimiliki oleh petani juga menjadi penghambat dalam peningkatan produksi (Perusahaan Negara Perkebunan XVI Laporan Tahunan 1980, 1980: 85-95).
Penolakan petani di lahan sawah diakibatkan pula oleh banyaknya oknum yang tidak bertanggung jawab dalam Program TRI. Pegawai KUD (Koperasi Unit Desa) tidak menyalurkan kredit dan sarana produksi dengan baik. Para pejabat pemerintahan (lurah dan pejabat di tingkat atasnya) mengambil keuntungan sendiri dalam penyediaan lahan. Petani yang menolak juga dinterogasi oleh pihak keamanan di kantor Koramil (Komando Rayon Militer) (Wawancara dengan Sungadi). Petani yang merugi enggan untuk melapor kepada pemerintah karena takut dianggap tidak loyal dan tidak mengikuti program pemerintah (Wawasan, 3 Oktober 1990).

Semakin terbatasnya lahan sawah produktif untuk penanaman tebu mengharuskan pihak Pabrik Gula Mojo mencari solusi agar tetap memenuhi target produksi. Pemerintah Daerah Sragen melalui Surat Keputusan (SK) mengharuskan petani menanam tebu dengan sistem glebagan (giliran) untuk mengatasi masalah tersebut (Kedaulatan Rakyat, 6 September 1990). ${ }^{3}$ Setiap tiga tahun sekali, petani diwajibkan untuk menanam tebu. Keadaan ini memaksa pemerintah mengalihkan penanaman tebu ke lahan kering atau kritis. Pihak Pabrik Gula Mojo juga melakukan percobaan yang dimotori oleh Hadipramono, Sarijono, Suwarto, Gian Mario, serta Keman di lahan kering pada 1986-1987. Percobaan pertama dilakukan di Desa Plumbon seluas 0,4 ha, serta di Desa Gabus I dan III masing-masing seluas 0,7 ha dan 0,4 ha. Percobaan yang dilakukan di wilayah selatan Bengawan Solo tersebut ternyata mendapatkan hasil melebihi penanaman palawija (jagung dan singkong) yakni Rp 200.000 per hektar (Sinar Tani, 13 Juni 1990). ${ }^{4}$ Pabrik Gula Mojo memutuskan 
bahwa lahan kering co-cok untuk tanaman tebu. Pabrik Gula Mojo memiliki potensi lahan kering seluas 13.023 ha di sebelah utara Bengawan Solo (Sinar Tani, 16 Juni 1990). Pada masa tanam 1987/1988 Pabrik Gula Mojo menanam tebu seluas 274 ha di lahan kering, baik di selatan maupun utara Bengawan Solo (Sinar Tani, 16 Juni 1990).

Keberhasilan penanaman tebu lahan kering di wilayah kerja Pabrik Gula Mojo ditandai dengan penurunan luas lahan sawah yang digunakan untuk menanam tebu. Pada 1988 luas lahan sawah mencapai 3.396 ha, 2.819 ha pada 1989 , dan 1.670 ha pada 1990 . Sementara itu, luas lahan kering meningkat dari 2.600 ha menjadi 4.300 ha pada periode yang sama (Kedaulatan Rakyat, 6 September 1990). Keberhasilan penanaman tebu di lahan kering juga ditunjang oleh kebijakan pabrik yang mengolah limbah padat berupa blotong menjadi pupuk kompos yang digunakan untuk pemupukan di lahan kering. Selain itu, pihak pabrik terus mencari varietas baru yang cocok untuk ditanam di lahan kering bekerja sama dengan P3GI (Pusat Penelitian Perkebunan Gula Indonesia) Pasuruan (Sinar Tani, 16 Juni 1990).

\section{Dampak Sosial-Ekonomi Program TRI}

\section{Produktivitas Pabrik Gula Mojo}

Pelaksanaan Program TRI di wilayah PNP XVI Surakarta tidak mampu meningkatkan produktivitas tebu yang dihasilkan. Produktivi-tas (kw/ha) tebu justru mengalami penurunan. Produktivitas mengalami penurunan dari $1.869 \mathrm{kw} / \mathrm{ha}$ (TRIS I + TRIS II) pada 1976-1977 menjadi $1.578 \mathrm{kw} / \mathrm{ha}$ pada 1979-1980 (Perusahaan Negara Perkebunan XVI Laporan Tahunan 1980, 1980: 87). Sementara itu, pelaksanaan
Program TRI di wilayah kerja Pabrik Gula Mojo selama 10 tahun sebenarnya mampu meningkatkan luas lahan tebu yang digiling. Pada 1975-1976, ketika hanya TRI II yang dijalankan, luas lahan Pabrik Gula Mojo hanya $2.465,79$ ha dengan produksi 2.121.832 kw. Luas lahan meningkat menjadi 3.807,914 ha pada 1984-1985 dengan produksi 2.835.272 kw. Akan tetapi, produktivitas Pabrik Gula Mojo menurun secara drastis pada 1981-1982 dengan produktivitas sejumlah $646 \mathrm{kw} / \mathrm{ha}$, rendemen 9,82\%, serta hablur 63,44 kw/ha. Tingkat rendemen juga seringkali mengalami penurunan. Rendemen tertinggi justru dapat dicapai pada 1975-1976 dengan 11,48 dan tidak pernah melampaui angka tersebut lagi selama 10 tahun awal pelaksanaan Program TRI. Tingkat rendemen bahkan hanya 7,72 pada 1982-1983 (Satuan Bimas Kabupaten Sragen, 1988).

Penurunan produktivitas disebabkan karena pengolahan tanah diborongkan sehingga hasilnya tidak sempurna, ketepatan waktu tanam yang mundur dan saat penebangan pangkal tebu yang mengandung banyak gula tidak ikut serta ditebang. Alih teknologi dari pabrik gula ke petani tidak terlaksana secara maksimal karena petani lebih terbiasa menanam padi di lahan sawahnya. Keadaan ini mengindikasikan bahwa keberhasilan pemerintah, dalam Program TRI, hanya terletak pada ekstensifikasi lahan pertanian, bukan pada intensifikasi yang menjadi tujuan dari Porgram TRI.

\section{Dampak terhadap Petani TRI dan Masyaakat di Lahan Sawah}

Selama lima tahun awal pelaksanaan Program TRI, pendapatan petani di wilayah PNP XVI Surakarta mengalami peningkatan. Pendapatan petani meningkat

$4 \quad$ Petani di Desa Plumbon memperoleh pendapatan sebesar Rp 878.051 per hektar, di Desa Gabus I sebesar Rp 446.610, dan di Desa Gabus III mendapatkan Rp 970.080. 
dari Rp 414.051,67/ha pada 1976-1977 menjadi Rp 909.091,54/ha pada 1979-1980 untuk Program TRIS I di wilayah PNP XVI Surakarta. Sementara itu, pada Program TRIS II pendapatan petani meningkat dari $R p$ 419.546,27/ha pada 1975-1976 menjadi $\mathrm{Rp} 822.228,77 /$ ha pada $1979-1980$ (Perusahaan Negara Perkebunan XVI
Laporan Tahunan 1980, 1980: 88-91). TRIS II ternyata lebih menguntungkan bagi petani dibandingkan dengan TRIS I karena membutuhkan waktu yang lebih pendek dan menghasilkan pendapatan yang lebih besar pula (Perusahaan Negara Perkebunan XVI Laporan Tahunan 1980, 1980: 93). ${ }^{5}$

\section{Pendapatan Petani TRI di Wilayah PNP XVI Surakarta 1975-1980}

\begin{tabular}{|c|l|l|}
\hline Tahun & \multicolumn{1}{|c|}{ TRIS I } & \multicolumn{1}{|c|}{ TRIS II } \\
\hline $1975 / 1976$ & - & $\operatorname{Rp~419.546,27/ha~}$ \\
\hline $1976 / 1977$ & $\operatorname{Rp~414.051,67/ha~}$ & $\operatorname{Rp~478.086,02/ha~}$ \\
\hline $1977 / 1978$ & $\operatorname{Rp~452.478,08/ha}$ & $\operatorname{Rp~461.459,35/ha~}$ \\
\hline $1978 / 1979$ & $\operatorname{Rp} 722.670,21 / \mathrm{ha}$ & $\operatorname{Rp~} 615.518,35 / \mathrm{ha}$ \\
\hline $1979 / 1980$ & $\operatorname{Rp} 909.091,54 / \mathrm{ha}$ & $\operatorname{Rp~} 822.228,77 / \mathrm{ha}$ \\
\hline
\end{tabular}

Sumber: Perusahaan Negara Perkebunan XVI Laporan Tahunan 1980 hlm. 88-91.

Berdasarkan capaian SHU (Sisa Hasil Usaha) KUD di wilayah kerja Pabrik Gula Mojo yang menjalnkan Program TRI, pendapatan petani mengalami peningkatan. Pada musim tanam 1981-1982 SHU yang dihasilkan adalah $\mathrm{Rp}$ 598.858. Secara berturut-turut hingga musim tanam 19851986, KUD pelaksana Program TRI mampu menghasilkan SHU sebesar Rp 408.421, Rp 585.480, Rp 812.346, dan 1.007.354 (Kedaulatan Rakyat, 22 September 1987). Pendapatan petani dari penanaman tebu Program TRI mempunyai nilai yang lebih tinggi jika dibandingkan dengan sewa tanah yang masih diterapkan. Pada 19771978, besarnya sewa tanah yang ditetapkan melalui SK. Menteri Dalam Negeri No. 163 tahun 1977 adalah Rp 230.000-Rp 253.000/ ha (rata-rata: Rp 241.500/ha). Sementara itu, menurut SK. Menteri Dalam Negeri No. 164 tahun 1977 besarnya sewa tanah adalah Rp 264.500-Rp 287.500/ha (rata-rata: Rp 276.000) (Perusahaan Negara Perkebunan XVI Laporan Tahunan 1980, 1980: 93). ${ }^{6}$

Pendapatan petani dari penanaman tebu Program TRI yang mengalami kenaikan masih lebih rendah jika dibandingkan usaha tani padi dan palawija. Usaha tani padi dan palawija mampu menghasilkan pendapatan sebesar $\operatorname{Rp} 1.032 .747,30 /$ ha selama 16 bulan (masa TRIS I) dan Rp 793.685,80/ ha selama 12 bulan (masa TRIS II) pada 1979/1980 (Perusahaan Negara Perkebunan XVI Laporan Tahunan 1980, 1980: 93). Program TRI mengalami kegagalan dalam menempatkan petani sebagai tuan rumah di atas tanahnya sendiri. Tingkat produktivitas

$5 \quad$ TRIS I membutuhkan waktu hingga 16 bulan, sementara TRIS II selama 12 bulan. Selain itu, pada musim tanam 1976/1977 TRIS II di wilayah PNP XVI Surakarta telah mampu menghasilkan pendapatan sejumlah Rp 418.086,02/ha sedangkan TRIS I hanya Rp 354.051,67/ha.

6 Besarnya uang sewa masih harus ditambah dengan premi serah tanah, premi produksi, premi dongkelan, dan premi kasepan jika pengembalian kepada pemilik tanah melampaui waktu yang ditentukan. SK tersebut berlaku hingga 1979/1980. 
dan rendemen yang rendah menjadikan pendapatan petani tidak sesuai dengan apa yang diharapkan. Para petani bahkan lebih memilih menyewakan tanah mereka kepada para petani besar yang telah menjalin kerja sama dengan pihak pabrik gula (Mubyarto, 1984:81).

\section{Perbandingan Pendapatan dari Usaha Tani Petani}

\begin{tabular}{|l|c|c|}
\hline \multirow{1}{*}{ Pendapatan diperoleh dari } & $\begin{array}{c}\text { TRIS I } \\
\text { Selama } 16 \text { bulan (rata-rata } \\
\text { Rp/ha) }\end{array}$ & $\begin{array}{c}\text { TRIS II } \\
\text { Selama 12 bulan (rata-rata } \\
\text { Rp/ha) }\end{array}$ \\
\hline Persewaan Tanah & 355.000 & 282.500 \\
\hline Usaha tani tebu & $839.091,54$ & $619.333,44$ \\
\hline Usaha tani padi dan palawija & $1.032 .747,30$ & $793.685,80$ \\
\hline
\end{tabular}

Sumber: Perusahaan Negara Perkebunan XVI Laporan Tahunan 1980 halaman 94.

Keengganan petani untuk berpartisipasi dalam Program TRI direspons keras oleh pemerintah. Petani yang menolak Program TRI diinterogasi oleh pihak keamanan yakni ABRI (Angkatan Bersenjata Republik Indonesia) (Wawancara dengan Sungadi), hingga memunculkan istilah "ABRI masuk gadangan" (Suara Merdeka, 23 September 1985). Petani terpaksa untuk melaksanakan Program TRI dibawah tekanan yang kuat dari pemerintah. Aspirasi petani juga tidak terakomodasi dengan baik. Akhirnya, petani melakukan protes sosial dalam bentuk pembakaran lahan tebu Program TRI.

Beberapa peristiwa pembakaran tebu terjadi selama pelaksanaan Program TRI di wilayah kerja Pabrik Gula Mojo. Pembakaran terjadi di Desa Banaran, Kecamatan Sambungmacan, yakni lahan tebu TRI seluas 25,3 ha diduga dibakar secara sengaja pada Jum'at, 17 Agustus 1990 (Suara Merdeka, 21 Agustus 1990). Lahan tersebut merupakan milik sekitar 70 petani TRI. Keresahan dialami petani karena tebu yang seharusnya sudah ditebang mengalami keterlambatan hingga dua minggu. Kerugian akibat kebakaran tersebut diperkirakan mencapai Rp 30 juta. Di Desa Duyungan, Kecamatan Sidoharjo, para petani juga membakar lahan tebu
TRI pada Oktober 1990 (Wawasan, 9 Oktober 1990). Para petani merasa kesal karena belum dilaksanakannya penebangan tebu. Penundaan penebangan tebu akan menurunkan kandungan rendemen dan merugikan petani. Lahan seluas 17 ha yang dimiliki oleh 51 petani sengaja dibakar dengan sebuah perencanaan. Indikasi tersebut didasarkan pada kenyataan bahwa api berasal dari bagian tengah perkebunan tebu. Para petani sebenarnya enggan untuk menanam tebu tetapi, karena mereka merasa sungkan dengan kepala desa, maka hal tersebut terpaksa dilaksanakan.

Pemicu lain keengganan petani di wilayah lahan sawah untuk menanam tebu adalah permainan pihak Pabrik Gula Mojo dalam menentukan kandungan rendemen tebu. Masyarakat yang telah menanam tebu sesuai dengan prosedur, harus menerima kekecewaan setelah tebu yang mereka tanam memiliki kandungan rendemen rendah. Rendemen tebu yang sebenarnya tinggi, dikatakan rendah oleh pihak pabrik. Keadaan ini menguntungkan pihak pabrik karena membayar tebu dari petani dengan harga yang tidak semestinya. Sementara itu, keadaan ini sangat merugikan bagi petani. Dampak jangka panjang yang dialami pihak 
pabrik adalah adanya keengganan petani untuk menjual hasil tebu mereka ke Pabrik Gula Mojo dan memilih untuk menjual tebu ke pabrik lain seperti Gondang Baru dan Madukismo (Wawancara dengan Sungadi).

\section{Dampak terhadap Petani TRI dan Masyarakat di Lahan Kering}

Berbeda dengan lahan sawah, petani dan masyarakat di lahan kering, terutama di sebelah utara Bengawan Solo, merasakan manfaat dari pelaksanaan Program TRI di wilayah mereka. Sebelum diterapkannya program TRI, pendapatan petani di lahan kering dari penanaman komoditas seperti padi gogo, jagung, kacang tanah, dan ketela pohon berkisar antara Rp 370.000 hingga Rp 500.000/ha/tahun. Setelah dilakukannya penanaman tebu TRI dibawah PTP XVXVI, penghasilan petani (Sisa Hasil Usaha) meningkat menjadi Rp 681.526 - Rp 1.111.073 atau rata-rata $\mathrm{Rp} 850.000 /$ ha/tahun sejak 1983/1984 (Sinar Tani, 6 Juni 1990). Sementara itu, percobaan yang dilakukan pihak Pabrik Gula Mojo di lahan kering mampu menghasilkan pendapatan melebihi penanaman palawija ( $\mathrm{Rp} 200.000$ ) yakni berkisar antara Rp 400.000 - Rp 900.000 (Sinar Tani, 13 Juni 1990). ${ }^{7}$

Sebenarnya usaha tani tebu TRI yang berkembang di lahan kering hanyalah TRI fiktif karena kelembagaan yang diperlukan oleh Program TRI tidak semuanya terpenuhi, seperti Kelompok Tani, KUD, serta kredit kepada petani (Dibyo Prabowo, 1994:23), serta masih terjadinya penyewaan lahan. Masyarakat beranggapan bahwa penyewaan tanah lebih menguntungkan daripada tanah tidak dimanfaatkan sama sekali (Wawancara dengan Sulamso). Salah satu pengusaha yang menyewa lahan masyarakat ialah Imam Soejono, pemilik C.V. Amarta
Bumi. Masyarakat bersedia menyewakan lahannya dengan uang sewa sekitar Rp 50.000/ha/tahun. Kesediaan masyarakat untuk menyewakan lahannya dipicu karena masyarakat tidak dapat memanfaatkan lahan mereka untuk lahan pertanian maupun perkebunan sebelum masuknya tanaman tebu di wilayah lahan kering. Meskipun penyewaan lahan sebenarnya dilarang, Program TRI tetap dijalankan karena penyewaan lahan menguntungkan masyarakat. Hal tersebut menjadi alasan program ini tetap dilaksanakan meski melanggar aturan pelaksanaannya (Wawancara dengan Sumanto).

Petani menggunakan uang sewa lahan untuk mendapatkan beberapa fasilitas yang, sebelum masuknya Program TRI, belum mereka peroleh. Masyarakat di wilayah kelurahan Dawung, Kecamatan Jenar misalnya, menggunakan uang hasil sewa lahan untuk mendapatkan jaringan listrik (Wawancara dengan Sulamso). Penanaman tebu Program TRI mampu menciptakan lapangan kerja baru bagi masyarakat. Arus urbanisasi yang semula tinggi dapat ditekan dengan adanya tebu di lahan kering. Pada awalnya masyarakat lebih memilih untuk melakukan urbanisasi ke kota-kota besar yang menyediakan lapangan pekerjaan lebih banyak. Di kota-kota besar masyarakat bekerja sebagai tukang becak, kuli bangunan, kuli pabrik, pembantu rumah tangga, dan buruh kasar (Sinar Tani, 13 Juni 1990). Masyarakat mendapatkan pendapatan yang rendah dari pekerjaan yang dijalaninya. Setelah masuknya tebu di wilayah lahan kering, masyarakat lebih memilih untuk melakukan pekerjaan penanaman dan perawatan tebu lainnya meski pendapatannya tak berbeda jauh dengan pekerjaan yang mereka jalani di kota besar. 
Tingkat pendidikan masyarakat juga meningkat seiring tersedianya dana dari penanaman tebu Program TRI. Mereka yang semula hanya menyekolahkan anak mereka sampai jenjang Sekolah Dasar (SD) mulai memasukkan anak mereka ke jenjang yang lebih tinggi seperti Sekolah Menengah Pertama (SMP) (Wawancara dengan Mohari). Isolasi antar desa juga mulai terbuka, semenjak penanaman tebu Program TRI di lahan kering (Sinar Tani, 16 Juni 1990). Pembuatan jalan diperlukan sebagai sarana pengangkutan tebu menggunakan truk. Wilayah yang semula menjadi tempat tinggal satwa liar seperti babi hutan dan rusa berubah menjadi lokasi hilir-mudik truk-truk pengangkut tebu di lahan kering. Masyarakat di sekitar lahan kering juga memanfaatkan jalur yang telah dibuat untuk memudahkan mobilisasi.

Pelaksanaan Program TRI di wilayah kerja Pabrik Gula Mojo Sragen memberikan dampak mendalam bagi kondisi sosial-ekonomi masyarakat Sragen, terutama petani. Petani di wilayah sawah menolak menanam tebu karena penanaman padi lebih menguntungkan. Pelaksanaan Program TRI memiliki kemiripan dengan sistem tanam paksa pada masa kolonial yang memanfaatkan keberadaan pejabat lokal, perintah untuk menanam tebu, tekanan terhadap petani melalui intervensi pihak keamanan, serta bertujuan untuk menghasilkan produksi gula dalam jumlah besar. Sementara itu, petani di wilayah lahan kering mendukung pelaksanaan Program TRI karena lebih menguntungkan jika dibandingkan penanaman tanaman lainnya. Perbedaan kondisi wilayah, terutama tanah, memberikan dampak berbeda bagi kondisi sosial-ekonomi petani.

\section{Kesimpulan}

Korporatisme pedesaan pada masa Orde Baru yang dijalankan melalui Program TRI menunjukkan suatu hubungan langsung negara dengan rakyat, terutama petani tebu, dalam usaha meningkatkan kesejahteraan petani. Peran petani tebu untuk memproduksi gula ditingkatkan dalam sebuah korporasi, bersama beberapa pihak yang terlibat, demi tercapainya tujuan bersama yakni swasembada gula. Petani, dalam Program TRI, harus menjalankan produksi mulai dari penanaman hingga masa panen denagan kondisi alih teknologi yang belum terlaksana secara maksimal. Keadaan tersebut mengakibatkan resiko yang harus ditanggung oleh petani menjadi lebih besar. Program TRI hanya menjadi potret pelimpahan tanggung jawab produksi gula dari pabrik gula kepada petani.

Pelaksanaan Program TRI memiliki kemiripan dengan cultuurstelsel (sistem tanam paksa) yang telah dijalankan sejak 1830, pada masa Gubernur Jenderal van den Bosch. Secara sistematis program TRI memanfaatkan keberadaan pejabat lokal, perintah untuk menanam tebu, tekanan terhadap petani melalui intervensi pihak keamanan, serta bertujuan untuk menghasilkan produksi gula dalam jumlah besar. Meskipun secara sistem mirip dengan cultuurstelsel tetapi Program TRI dilaksanakan ketika gula sudah tidak menjadi komoditas utama pemerintah karena tekanan produksi beras. Harga gula dalam negeri juga terlampau tinggi jika dibandingkan dengan harga gula internasional. Fasilitas yang diberikan pemerintah kepada petani belum mampu meningkatkan produktivitas gula dalam negeri. Petani memiliki kekuasaan lebih rendah jika dibandngkan dengan lembaga lain yang terlibat dalam Program TRI. Tujuan Program TRI untuk menempatkan petani sebagai tuan rumah di atas tanahnya sendiri tidak dapat tercapai.

Keterlibatan berbagai pihak dalam Program TRI menjadikan pelaksanaan Program TRI tidak maksimal. Masing-masing pihak membawa kepentingan sendiri untuk dapat 
dicapai. Oknum-oknum yang tidak bertanggung jawab menimbulkan munculnya permasalahan seperti pencairan kredit yang bermasalah, tingkat rendemen yang rendah, serta penebangan tebu yang terlambat. Kerugian yang harus diderita oleh petani menjadi lebih besar karena petani merupakan pelaksana utama proses produksi gula.

Pelaksanaan Program TRI di wilayah kerja Pabrik Gula Mojo Sragen memiliki dampak berbeda terhadap petani. Petani di wilayah selatan Bengawan Solo menolak dilaksanakannya Program TRI di lahan sawah mereka. Pendapatan petani menurun ketika menanam tebu Program TRI jika dibandingkan dengan menanam padi. Penolakan petani terhadap usaha tani tebu TRI dilakukan dalam bentuk protes sosial. Protes sosial dilakukan dengan membakar lahan tebu. Pembakaran tebu merupakan akumulasi dari kekesalan petani karena mekanisme Program TRI yang tidak dijalankan sebagaimana semestinya.

Kehadiran negara dalam mengatasi adanya penolakan petani untuk menanam tebu TRI ditunjukkan dengan peran aparat keamanan, ABRI (Angkatan Bersenjata Republik Indonesia), menginterogasi petani yang menolak. Kehadiran aparat keamanan memunculkan istilah "ABRI masuk gadangan" yang berperan dalam menjamin lancarnya pelaksanaan TRI. Penolakan dan keluhan petani tidak terakomodasi dengan baik. Otoritas negara yang lebih besar daripada petani, menjadikan petani tidak mampu menolak dan menerima program pemerintah sebagai bentuk pengorbanan untuk negara. Petani hanya menjadi agen pembangunan pemerintah yang tidak dapat menikmati posisinya.

Berbeda dengan pelaksanaan Program TRI di lahan sawah, pihak Pabrik Gula Mojo memfokuskan pada usaha tani tebu di lahan kering untuk mengatasi kesulitan dalam penyediaan lahan sawah bagi usaha tani tebu TRI, terutama di sebelah utara Bengawan Solo. Tanah yang belum dimanfaatkan, sebelum masuknya Program TRI, disewakan oleh masyarakat kepada pengusaha atau petani bermodal besar untuk ditanami tebu. Persewaan lahan yang sebenarnya dilarang dalam Program TRI tetap berjalan karena mampu memberikan penghasilan yang lebih besar bagi petani. Budidaya tebu TRI di lahan kering mampu meningkatkan taraf hidup petani dan masyarakat. Ketimpangan sosial-ekonomi dengan wilayah selatan Bengawan Solo mulai teratasi karena usaha tani tebu TRI mampu menciptakan lapangan pekerjaan baru bagi masyarakat. Sarana transportasi berupa jalan mulai terbuka dan isolasi antar wilayah dapat teratasi sehingga akses masyarakat untuk mendapatkan informasi semakin mudah.

Pendapatan masyarakat dari sewa tanah digunakan untuk pemasangan listrik dan biaya pendidikan. Budidaya tebu TRI mampu memperbaiki keadaan sosial-ekonomi masyarakat di sebelah utara Bengawan Solo. Meskipun Program TRI yang berkembang hanyalah TRI fiktif, yang lebih menguntungkan bagi petani besar atau pengusaha, tetapi kehadiran TRI di wilayah utara Bengawan Solo mampu memberikan dampak positif bagi masyarakat.

Berkembangnya Program TRI di wilayah kerja Pabrik Gula Mojo ke wilayah kering tidak mampu meningkatkan produktivitas tebu yang dihasilkan sebagai salah satu tujuan TRI. Tingkat rendemen juga mengalami penurunan. Peningkatan produksi bukan dicapai dengan intensifikasi pertanian melainkan ekstensifikasi (perluasan lahan) ke lahan kering. Meskipun demikian, Program TRI di wilayah kerja Pabrik Gula Mojo yang mengalami kegagalan mampu memberikan dampak positif bagi petani dan masyarakat di wilayah sebelah utara Bengawan Solo. 
Selama ini, penelitian mengenai Program TRI memberikan gambaran bahwa pelaksanaan program tersebut berdampak buruk terhadap petani karena pendapatan yang menurun. Program TRI hanya mengalihkan tanggung jawab produksi gula dari pabrik gula terhadap petani. Akan tetapi, penelitian ini membuktikan bahwa pelaksanaan program TRI mampu meningkatkan kondisi sosial-ekonomi petani, terutama di lahan kering. Walaupun pelaksaan sistem TRI tidak berjalan secara maksimal, Program TRI masih mampu memberikan dampak positif bagi petani.

\section{Daftar Pustaka}

\section{Arsip}

Himpunan Peraturan-peraturan TRI Tahun 1981, P.T. Perkebunan XV-XVI (Persero) Jawa Tengah.

Perusahaan Negara Perkebunan XVI Laporan Tahunan 1980.

Satuan Bimas Kabupaten Sragen, "Sedikit Mengenai Pergulaan di Indonesia. Program Pemerintah/Inpres No. 9 Th.1975” Penataran Ketua Kelompok Tebu Rakyat Intensifikasi Mt. 1987/1988 Wilker P.G. Mojo Sragen.

\section{Buku}

Deuster, Paul R. 1982. "Revolusi Hijau" di Desa Sumatera Barat dan Desa Sulawesi Selatan" dalam Sajogyo (ed.). Bunga Rampai Perekonomian Desa. Bogor: Yayasan Obor Indonesia.

Dibyo Prabowo. 1994. Penguasaan Tanah dalam Program TebuRakyat Intensifikasi. Yogyakarta: Gadjah Mada University Press.
Mackie, Jamie. 1992. "Dualism and Market Segmentation in Indonesia", dalam M. Arsjad Anwar, Thee Kian Wie, dan Iwan Jaya Azis (eds.). Pemikiran Pelaksanaan, dan Perintisan Pembangunan Ekonomi. Jakarta: Gramedia Pustaka Utama.

Mubyarto. 1996. Ekonomi Pertanian dan Pedesaan, Yogyakarta: Aditya Media. 1984. Masalah Industri Gula di Indonesia, Yogyakarta: BPFE.

Mubyarto dan Daryanti. 1991. Gula: Kajian Sosial Ekonomi, Yogyakarta: Aditya Media.

Ricklefs, M.C. 2008. Sejarah Indonesia Modern 1200-2008. Jakarta: Serambi.

Selo Soemardjan dan Breazeale, Kennon. 1993. Cultural Change in Rural Indonesia Impact OF Village Development. Surakarta: Sebelas Maret University Press.

Sjahrir. 1992. Refleksi Pembangunan Ekonomi Indonesia 1968-1992. Jakarta: Gramedia Pustaka Utama.

Soentoro, Novi Indiarto, dan Abd. Muis S. Ali. 1999. Usaha Tani Tebu dan Tebu Rakyat Intensifikasi di Jawa, dalam M. Husein Sawit, P. Suharno, Anas Rachman (eds.) Ekonomi Gula di Indonesia. Jakarta: Penerbit Institut Pertanian Bogor.

van Zanden, Jan Luiten, dan Marks, Daan. 2012. Ekonomi Indonesia 18002010: Antara Drama dan Keajaiban Pertumbuhan, Jakarta: Penerbit Buku Kompas.

Gosh, Jayati. 1996. "Coercive Corporatism: The State in Indonesian Capitalism", Social Scientist 24, 11/12. 
Hansen, Garry. 1972. "Indonesia's Green Revolution: The Abandonment of a NonMarket Strategy toward Change", Asian Survey $12,11$.

Knight, G. Roger. 2012. "From Merdeka! to massacre: The politics of sugar in the early years of the Indonesian republic", Journal of Southeast Asian Studies 43, 3.

Mackie, Jamie and O'Malley, W. J. 1988. "Productivity Decline in the Java Sugar Industry from an Olsonian Perspective", Comparative Studies in Society and History 30, 4.

\section{Karya Tulis, Skripsi, Tesis, dan Disertasi}

Daniel Asnur. 1999. Pelaksanaan Kebijakan Tebu Rakyat Intensifikasi (TRI). Jakarta: Departemen Koperasi, Pengusaha Kecil dan Menengah Badan Penelitian dan Pengembangan Koperasi Pengusaha Kecil dan Menengah.

Jati Isnanto. 2012. Pelaksanaan Program Tebu Rakyat Intensifikasi di Kabupaten Klaten 1975-1997. Skripsi Universitas Negeri Yogyakarta.

\section{Surat Kabar}

Kedaulatan Rakyat, Selasa, 22 September 1987.

Kedaulatan Rakyat, Kamis, 6 september 1990.

Kompas, Kamis, 13 Desember 1990.

Sinar Tani, Rabu, 6 Juni 1990.
Sinar Tani, Rabu, 13 Juni 1990.

Sinar Tani, Sabtu, 16 Juni 1990.

Suara Karya, Kamis, 10 Januari 1985.

Suara Merdeka, Senin, 23 September 1985.

Suara Merdeka, Minggu, 12 April 1987.

Suara Merdeka, Selasa, 21 Agustus 1990.

Wawasan, Rabu, 3 Oktober 1990.

Wawasan, Selasa, 9 oktober 1990.

\section{Internet}

www.sragenkab.go.id, diakses pada Senin, 21 September 2015, pukul 0:07 WIB.

Kaman Nainggolan, "Kebijakan Gula Nasional dan Persaingan Global”, (www. academia.edu, diakses pada Kamis, 27 Agustus 2015, pukul 11:06 WIB).

Tjahjono Edi P, "Manisnya Tebu, Pahitnya Nasib Petani Tebu Rakyat Intensifikasi", (www.minihub.org, diakses pada Senin, 24 agustus 2015 pukul 14:10 WIB).

\section{Wawancara}

Wawancara dengan Sungadi, 65 tahun, pada 18 Mei 2014, pukul 16:00 WIB, dan 10 September 2015, pukul 8:00 WIB.

Wawancara dengan Sulamso, 67 tahun, pada 9 September 2015, pukul 17:00 WIB.

Wawancara dengan Mohari, 75 tahun, pada 6 November 2015, pukul 8:45 WIB.

Wawancara dengan Sumanto, 56 tahun, pada 8 November 2015, pukul 18:40 WIB. 